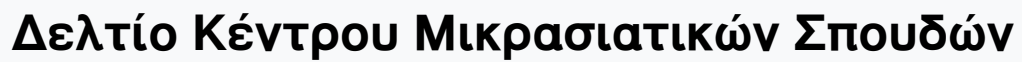

Tóp. 9 (1992)

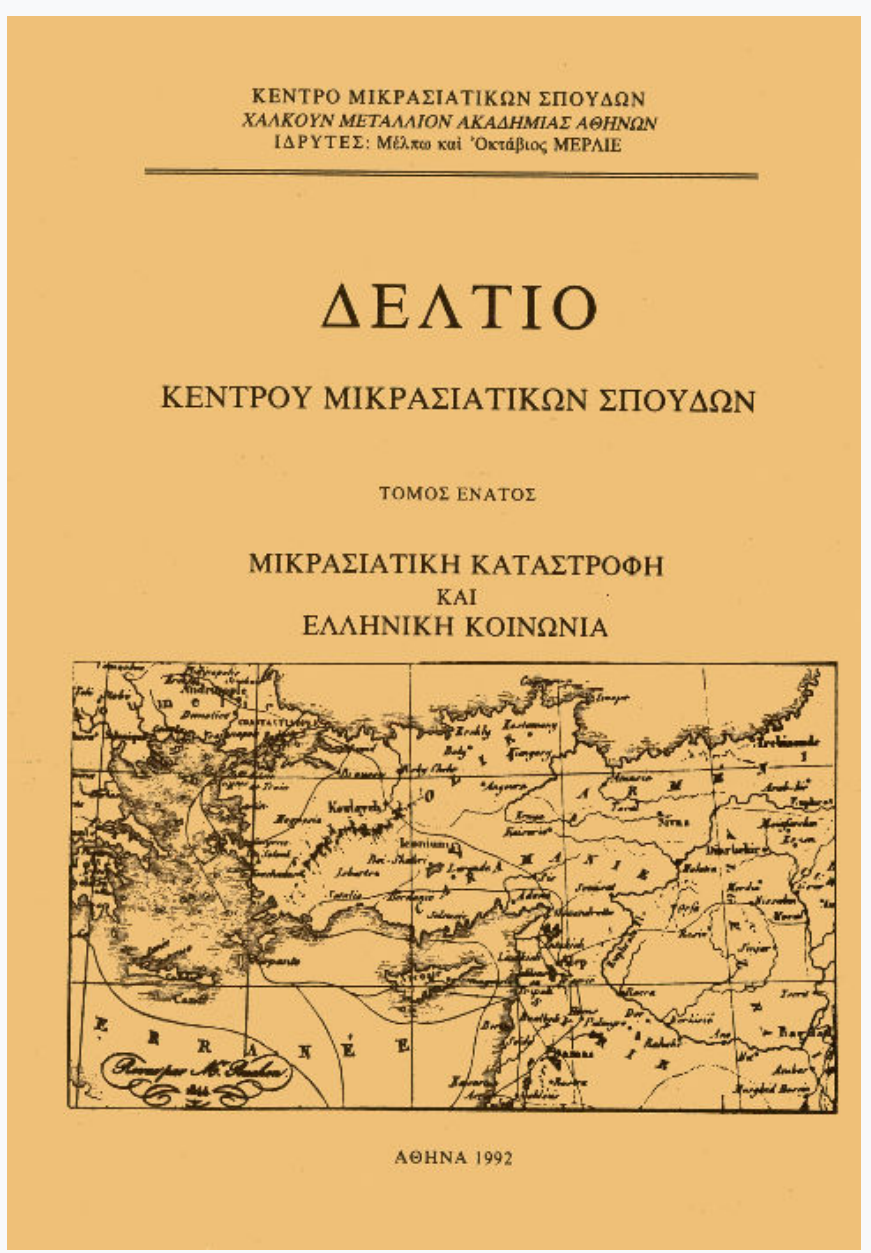

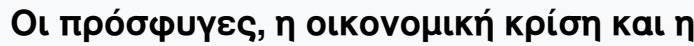

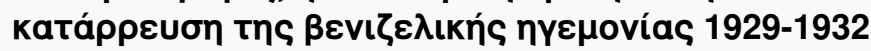

Mark Mazower

doi: $10.12681 /$ deltiokms.133

Copyright @ 2015, Mark Mazower

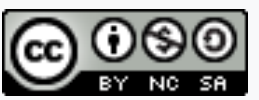

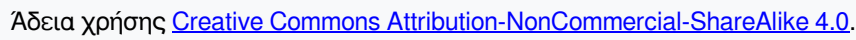

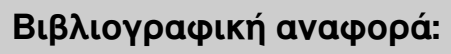

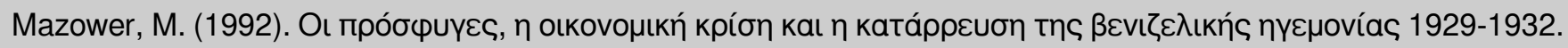

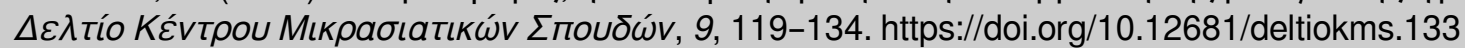


MARK MAZOWER

\section{THE REFUGEES, THE ECONOMIC CRISIS AND THE COLLAPSE OF VENIZELIST HEGEMONY, 1929-1932}

In the spring of 1932, John Drosopoulos warned that «Greece must organise herself as an up-to-date economic state, and tend to increase her production by improving the imperfect means now in use in order that she may become as self-sufficient as possible.... ${ }^{1}$ His was by no means the first such warning. With memories of prewar emigration fresh in the mind, reinforced by new doubts about Greece's "viability", commentators in the interwar period constantly stressed the need for domestic economic growth. Development economists would be inclined to pose the alternative paths to such growth in terms of a choice between import-substitution and exports; in practice, at least before 1932, Greek policy-makers saw these as complementary rather than alternatives. Another, more fundamental, strategic choice confronted them instead - that between rapid industrialisation or promoting growth through agriculture.

This was the choice which confronted modernising elites throughout Europe between the world wars. Ataturk in Turkey and Bethlen in Hungary concentrated their efforts on industrial growth, and used a heavy hand in the rural areas to force the farming population into acquiescence; Stalin's policy was a more extreme version of the same strategy. In Rumania, Bratianu's Liberals also sought to industrialise, but were handicapped by strong peasant opposition within a more democratic polity. Basically, it was difficult for democratic regimes to bear the social costs of rapid industrialisation. For a largely agrarian society, modernisation and capital accumulation within a democratic framework implied giving priority to agriculture over industry. This route may have involved a slower rate of growth than one which squeezed the

1. National Bank of Greece, Report for the Year 1931 of the Governor of the National Bank of Greece, Athens 1932, p. 44. 
rural sector dry, but it opened up new political possibilities. In Greece, to put it simply, the land reform, together with foreign loans, purchased peasant backing for Venizelist rule, pushing industrialisation into second place.

In terms of the impact upon economic growth, the arrival of the refugees in Greece offered both burdens and opportunities. The burdens were immediately obvious: the heavy financial costs of both short-term and long-term resettlement; the fears of "over-crowding» in an era plagued by demographic nightmares; the real social tensions between the newcomers and established Greek society. However, there were also benefits: quite apart from their entrepreneurial skills and initiative, the refugees also helped to "hellenise» the ethnic kaleidoscope of northern Greece, and held out the promise of an expanded domestic market and a cheap industrial workforce.

The immediate Venizelist response to the refugee influx in the early 1920s was to press ahead with the land reform. The Greek state shifted the costs of expropriation into the former owners of the land, freeing large areas which were eventually handed over to the Refugee Settlement Commission. Underlying the agrarian bias of Venizelist policy was a fundamental political calculation. The Great War, Venizelos warned, had radicalised the masses and created the danger "of seeing the peasants, workers of the fields, and the industrial workers in the towns united in overturning the lawful state ( $\tau \dot{0} \kappa \rho \alpha ́ \tau o \zeta ~ \tau o \tilde{v}$ $v o ́ \mu o v) .{ }^{2}$ To forestall the threat of such a fatal coalition - intensified by the refugee influx - land reform was elevated into a central feature of the Venizelist project. Conservative apprehensions were thinly disguised behind the paeans to official policy. «If the patriotism of the ruling classes and the good sense of the refugees», declared the RSC in its final report, "continue to hold in check those doctrines which claim that the happiness and the progress of a nation can only be acquired by submitting to the rule of a group of fanatics, enemies of all enlightenment, persecutors of all liberties and all initiative; and if, in several dozen years... a strong race of peasants, born out of the mixing of all the elements of hellenism, secures... the prosperity of Greece, that result will have been due to the impulse originally given by the RSC». ${ }^{3}$

That the RSC, and the Greek State, were prompted by such fears should not blind us to their very real achievements. It is surely not necessary to describe here the RSC's enormous impact upon Greek agriculture. By 1929 over half a million refugees had been settled, mostly in the north. The RSC organised a cadastral survey, built houses, provided livestock, farming tools and technical advice. "What a miracle!» enthused Jacques Ancel in his classic study of the transformation of Macedonia. ${ }^{4}$

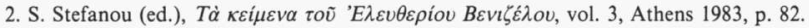

3. Bank of Athens, Bulletin, 100 (Dec. 1930), p. 1868.

4. Cited in Dimitris Pentzopoulos, The Balkan Exchange of Minorities and its Impact upon Greece, The Hague 1962. 
Such a verdict ignores the very real problems that accompanied the RSC's work - problems to which we shall return. But the important point is that no one could even have thought of passing a similar judgment upon the State's treatment of the urban refugees. Their continued neglect highlighted the stark strategic political choice which the State had made in favour of the countryside - what Venizelos himself termed "a paternal solicitude in favour of agriculture». The half a million or so refugees who settled in the cities lived in appalling squalor: two-thirds of the families visited by RSC staff were housed in temporary dwellings; over one-third were in «mere hovels which should be demolished at the earliest opportunityn. ${ }^{5}$ Greece's prewar urban housing crisis was intensified as the cities now coped with a massive increase in the pool of labour. Meanwhile, real wages fell through the 1920's, contributing to rapid industrialisation.

Venizelos himself, one of the few prominent politicians to show any enthusiasm for industrialisation at all, saw it as a way of absorbing the urban refugees into economic life. For that very reason, however, he was opposed to measures which raised the cost of labour and discouraged industrial investment. To a visiting delegate from the International Labour Office, Venizelos confirmed that «the urgent necessity of securing work for the great mass of refugees, the small proportion among them of male workers, and finally the necessity of dedicating all the available resources to the most urgent task of resettlement, have not permitted the implementation of measures which would be useful but might prevent the creation of new industries... and halt the development of othersm. ${ }^{6}$

Rather than creating a politically unreliable proletariat, subservient to sizeable industries, the State and the RSC preferred to encourage the urban refugees to form small businesses of their own. The "petty-bourgeois classes» were regarded as "valuable for social equilibrium». The National Bank prided itself in 1925 that its lending policies had «led tens of thousands of petty bourgeois refugees into production and regular life, creating from this passive element autonomous tiny economic units, rather than falling inevitably and fatefully victims of diverse subversive propaganda whose end result would be grievous

5. Messager d'Athènes, 28 July 1928; H. Morgenthau, I was Sent to Athens, New York 1929,

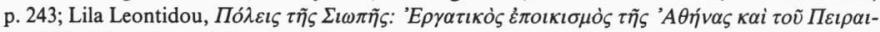
a, 1909-1940, Athens 1989, chs. 4-5.

6. FO $371 / 15960$ C2886/324, Velizelns-Simon, 3 April 1932, enclosing the ILO report "Les conditions du travail des salaires, de l'inuustrie et de commercen; A. Liakos, "O 'E $\lambda \varepsilon v \theta \varepsilon \dot{p} p r o \varsigma$

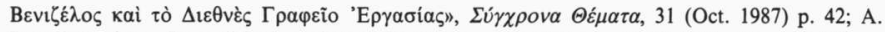
Papathanasiou, "La politique sociale de la Grèce", Les Balkans, 17-18 (Feb.-March 1932), p. 258-281. 
constitutional and social disturbances, if not uprisings». ${ }^{7}$ Such self-congratulation was, however, premature, for as numerous commentators pointed out, by leaving the organisation of industrial credit to the private sector rather than creating an equivalent to the Agricultural Bank, the State had allowed the fortunes of urban business to rise and fall with the market. After 1929, the supply of credit dried up, and many businesses ran into trouble. The collapse of the refugee-dominated carpet industry was to highlight the failure of official policy.

However, the political implications of this economic strategy for Venizelism took some time to emerge. Until the end of the 1920s, Venizelos's hold over refugee loyalties was secure. The appeal of the KKE was restricted by its sectarian infighting, its anti-agrarian line and its unpopular policy towards Macedonia. No other socialist party managed to bid successfully for the labour vote. The Socialist Workers Union, formed by prominent reformists, was quickly absorbed by Kafandaris's Venizelist faction. The truth was that Venizelos's enormous popularity left no room for a moderate socialist alternative. "So long as we live in a bourgeois state, let us live in it without being a revolutionary element opposed to the bourgeois economic policy of the state», wrote the editor of Kampana, a Mytilene newspaper which reflected the thinking of left-wing Venizelism. ${ }^{8}$ The 1928 election triumph was perhaps the highpoint of Venizelo's prestige in the inter-war period. But for some time afterwards, even prominent anti-Venizelists seemed content to see their arch-rival at the helm. "Every Greek in his right mind», remarked George Streit in early 1930, "must hope that [Venizelos] would be able to carry through his plan of building up the country economically». ${ }^{9}$ The most serious challenge to Venizelist hegemony would come not from anti-Venizelism, but from the gradual fragmentation of the Venizelist bloc, including key fractions of the refugee vote; the catalyst for this was the world economic crisis.

Refugee votes had, after all, won Venizelos the 1928 election and would be crucial in its sequel, due in 1932 at the latest. When the new-comers had first arrived in Greece, their intense loyalty to Venizelos had led them to turn a deaf ear to communism and other radical political options. Seven years later in Mytilene, a town where half the inhabitants were refugees, the sharp increase in support for the communists in the 1931 by-election-up from $7 \%$ to $21 \%$ since 1928 - was a worrying portent.

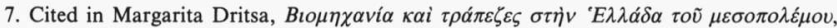
Athens 1990, p. 336.

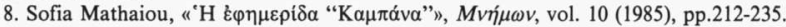

9. US National Archives, 868.00/626, Skinner (Athens) - State, 15 Jan. 1930. 
It is a measure of Venizelos' stature as a statesman that he had not allowed the threat of the refugee reaction to deter him from pursuing a rapprochement with the Turkish Government when he returned to power in 1928. This last act of inspired diplomacy culminated in several bilateral agreements signed in Ankara in October 1930. An essential preliminary, however, was the Convention signed that June which provided a definitive solution to the problem of liquidating the properties abandoned since 1922 by the Moslem and Greek Orthodox refugees. Since the Lausanne Convention the two governments had been unsuccessfully negotiating over this issue. Now they agreed to let each government enter into possession of the properties vacated by refugees from its teritory: the Greek Government took over formerly Moslem properties, and issued bonds to the refugees which provided for their partial indemnification by the state. The refugees greeted these arrangements with indignation and disappointment. They resented Venizelos' apparent acceptance of the Turkish argument that Greek properties in Asia Minor had amounted to less than those vacated by the Moslems in Greece. They bitterly attacked the Liberal Government for refusing to provide them with full compensation; and perhaps at a deeper level, they also reacted strongly to the idea that all their hopes of an eventual return to their former homes must now be given up. ${ }^{10}$

Venizelos believed that it was better for the refugees to adapt themselves as quickly as possible to their new life in Greece. The pro-government Ergasia admonished them in the spring of 1930, insisting that they uput an end to their demands and devote all their energy in this new economic environment to the development that would be decisive for their future». ${ }^{11}$ Venizelos could, after all, make the case that so far as the refugees were concerned, the counterpart to his emollient overtures to Ankara was the land reform and re-settlement programme at home. It was not by chance that the year of the Ankara Conention also saw the Greek Ministry of Agriculture and the new Agricultural Bank take over the functions of the Refugee Settlement Commission, which was now wound up: the tast of assisting the refugees was henceforth to fall to the Greek Government alone.

But Venizelos's diplomacy with Turkey was not the only cause of growing refugee dissatisfaction with the Liberal leader. By 1930, a number of underlying problems associated with the land reform had emerged. From the outset, legal uncertainties had bedevilled the question of property rights, and the

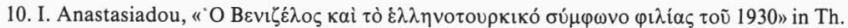

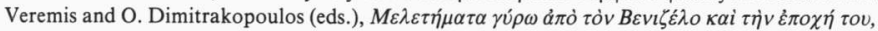
Athens 1980, pp. 309-426.

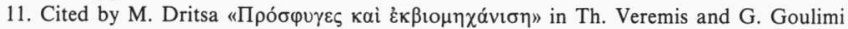

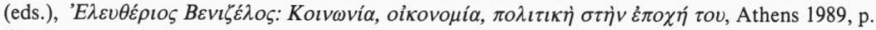
61. 
temporary allocation of land had discouraged farmers from making improvements. Told that their title to the land would only be granted once they had repaid their debt to the state in full, many beneficiaries of the land reform looked forward, if not to returning to Turkey, then to moving to the city, seeking work as wage-earners and shopkeepers.

Perhaps hardest hit among the resettled refugees were the tobacco growers. At the time that the RSC was distributing land, there was a boom in the tobacco market: prices were high, and land in tobacco-growing areas was distributed in plots so small that only intensive cash-crop cultivation was economic. At first the Government had been concerned that the departure of Muslim farmers would imperil the cultivation of the crop. Such fears proved unfounded. As tobacco exports soared, growing the crop was soon regarded as a way "not only to sustain the households of the producers of the region, but to bring those economically and psychologically shipwrecked human beings, refugees and native-born, to an island of paradise till then unknown, where wealth was as abundant as in a dream». By 1929 certain areas of eastern Macedonia and Thrace had become entirely dependent on tobacco, which had turned into the key commodity in the Greek economy. ${ }^{12}$

Money poured into the tobacco economy in the 1920s and by 1927 the National Bank was making more loans against tobacco than against any other crop. Producers set up "cooperatives" to take advantage of easily-available credit. "Ask producers who are not members if they have enrolled in cooperatives», wrote an observer, "I didn't need a loan up till now» they will tell you. According to some refugee smallholders: "Cooperative is a piece of paper which up to seven paidia sign and take to the bank to get money». ${ }^{13}$ By 1930 local bank managers were extremely worried at prevailing levels of indebtedness: credit was being spent on consumer goods, or wage labour, at levels which could only be sustained so long as the boom kept prices high.

As producer prices began to fall, two things happened: in the first place, growers were unable to pay their debts, putting the entire fragile credit structure of rural Greece - with its complex links between growers, merchants, money-lenders and banks - under increasing strain; second, growers began to face starvation, since for many of them, the plots they farmed were too small to allow them to retreat into self-sufficiency.

Faced with a threat to the banking system, the authorities felt impelled to act. But how, and for whose benefit? On the one hand, it seemed ludicrous to jeopardise the land reform by allowing the new smallholders to be bankrupted; yet debt relief was a potentially enormous expense for a government in no position to take on new commitments.

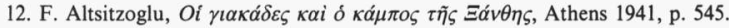

13. N. I. Anagnostopoulos, 'O ка́ $\mu \pi о \varsigma \tau \tilde{\nu} \nu \Sigma \varepsilon \rho \rho \tilde{\omega} v$, Athens 1937, pp. 72-73. 
Refugee farmers were particularly vociferous in calling for government action to scale down the debts they had incurred during the re-settlement. Many prosfygopateres (refugee "fathers") had attacked the RSC for supposedly exploiting the settlers financially in the interests of foreign bondholders. Once the RSC had been dissolved, the refugees directed their claims against the Greek state. Negotiations in the spring of 1930 between the RSC and the government did result in a number of decisions favourable to the refugees; the rate of interest on their debts was scaled down, whilst it was agreed they would not be charged various expenses incurred by the RSC. In effect, the Greek Government agreed to shoulder a large part of the settlement expenditure itself. ${ }^{14}$ But these concessions did not satisfy refugee leaders who continued to insist that the Greek state should have met all the costs of re-settling the newcomers.

Venizelos was not sympathetic to their demands. Touring northern Greece in May 1930, to explain his new Turkish policy, he made it clear that his Government would insist on the agricultural refugees repaying their debts to the state: it was not merely their moral duty, but also necessary if the remaining homeless refugee families were to be provided for. But this proved to be an extremely unpopular stance in the face of what one anti-Venizelist journalist called the "great crisis of rural Greece». Already at the 5th Tobacco Growers Congress, held in Salonika in January 1930, it was obvious that the Liberals had lost a lot of ground among the delegates to other parties, particularly the Agrarians. Despite a lengthy address by Gonatas, Governor-General of Macedonia, defending the Liberal Government's record, the Congress as a whole had a marked anti-Government, indeed anti-capitalistic tone. As support for the Agrarian Party grew in northern and central Greece over the coming months, Venizelos denounced what he described as "class parties". But Peitharchia, a Venizelist weekly critical of the Liberal leader's rhetorical excesses, pointed out that the problem did not lie in the revolutionary aspirations of the Agrarians: «the farmer of northern Greece is coming to believe that the cause of his misfortune is the insatiable capitalism which all bourgeois government serve, the present one especially. It is reality as well as the press which teaches him this. He learns that in the towns lives a mass of rich privileged people who enjoy cinemas, theaters, cars and a thousand other benefits while he works incessantly and goes hungry. Mr. Venizelos has promised him, or he thinks he has, wondrous good fortune. Instead of this, however, the support of the RSC has ended, likewise the loans... and in their place come failed harvests, the

14. S.P. Ladas, The Exchange of Minorities: Bulgaria, Greece and Turkey, New York 1932, pp. 692-696. 
worldwide economic crisis and sheer poverty. What is he supposed to do? $\aleph^{15}$

Not surprisingly, a new disillusionment with Venizelos, and a shift to more radical critiques of the capitalist path to development, spread through northern Greece. Reporting to Venizelos in March 1932, the nomarch of Cavalla warned that the Liberal Party had lost ground since 1928 in the countryside. His report vividly reveals the outlook and response of the local authorities:

The Communist Party... has acquired new followers even in the countryside, where three years ago one could say none existed. Of course I cannot say that those turning to communism are entirely conscious communists, but they are what one might call agrotokommounistai. That is, there are in the country areas men who are conscious communists and who through their constant teaching of the suffering farmers manage to indoctrinate villagers who, I repeat, do not really know about communism. Against these teachers of communism, who present themselves as agropateres, we are taking every preventive and repressive measure, thus enlightening the simple and ignorant folk. ${ }^{16}$

It is worth noting that in this report, the nomarch equated communism with membership of the Agrarian Party as well as with the KKE. What the authorities were reacting to, in other words, in the case of the agrarian crisis of the early 1930s was less the rise of the KKE than a more general radicalisation of that very part of the population, the rural smallholders, who had originally been seen as a bastion of the bourgeois order.

As they watched the "microbe of politics» spread through the countryside, it was obvious to the Liberals that they would have to do something more to retain the support of the smallholders they had helped bring into existence. Natural catastrophe pushed them into action: a series of harsh winters culminated in the storms and floods of 1930-31 which led starving peasants, chiefly shepherds and tobacco growers, to stream into the towns of northern Greece to receive the free maize distributed by the Agricultural Bank. ${ }^{17}$ As for the longer term measures which were clearly required, the first impulse of the Government was to look abroad. In July 1931 the Cabinet decided to seek the support of the League of Nations in raising money for a loan to consolidate the agricultural debt. But they could not have chosen a worse time in view of the chaos in international money markets. As a result they realised that the burden of relieving rural indebtedness would have to be borne by domestic rather than foreign creditors.

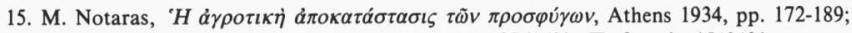

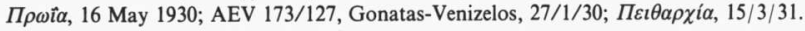

16. AEV 173/111, 26 March 1932.

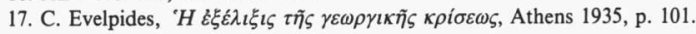


In October, on the eve of another bad winter, the Government suspended the direct land tax levied on most crops (though not on tobacco), declared a five-year moratorium on agricultural debts owed to private individuals and also suspended the seizure of farmers' properties against such debts. Provincial merchants, bank managers and local money-lenders all protested in vain: the Government had resolved to sacrifice their sympathies in order to win back the discontented beneficiaries of the land reform. ${ }^{18}$ The architect of these measures was Ioannis Karamanos, an Italian-trained agricultural expert and formerly a senior official in the RSC who had moved to become the director-general at the re-organised Ministry of Agriculture. Justifying the debt moratorium, Karamanos argued that «the Government has created a large class whose existence helps to maintain the social equilibrium of the country. In these circumstances, it must necessarily see with anxiety the forced sale of many small agricultural properties at low prices, to meet obligations assumed at a time when agricultural prices fetched high prices. The situation thus created may undo all the good done by the Government at such heavy cost». ${ }^{19}$

In particular these policies were felt to be necessary to stem the migration from the countryside into the towns. This exodus from the rural areas had alarmed commentators in Athens for several years. In December 1929, the cartoonist Demetriades published sketch entitled "The Last Farmer", showing a villager leading his donkey, wife and child off to Athens «to cultivate letters." According to Karavidas, an employee of the Agriculturak Bank, the problem lay in the basic fact that «the traditional aspirations of our rural population do not lie in farming... When the harvest is a success, the surplus is used to open a shop or to send the son to Athens to study law $»^{20}$. For many refugees there were pragmatic reasons for such attitudes: they had no permanent title to their land, and often did not come from farming backgrounds. Many left for the towns to work as labourers or, if they were lucky, to set up a shop with the money they had gained from selling off land and farming equipment $t^{21}$. As farm prices fell, the drift from the land continued, alarming many observers who doubted the capacity of the towns to support them. "The agricultural workers who go to the towns and cannot find employment in industry", wrote Karamanos, "would inevitably go to swell the ranks of those who depend for their

18. USNA 868.00/673, Morris Athens - State, 5 April 1932; FO 371/18403 R2908/2908, Waterlow Athens - FO, 2 May 1934.

19. League of Nations, The Agricultural Crisis, vol. 1 - Geneva 1931, p. 188; a laudatory portrait of Karamanos is in H. Morgenthau, I Was Sent to Athens, 270-272.

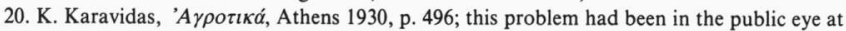
least as early as 1926, cf. Banque d'Athènes, Bulletin, no. 54 (February 1927).

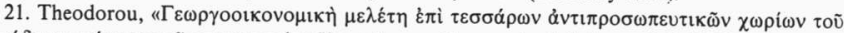

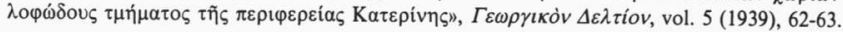


livelihood on parasitic trades or casual labour. This class is already numerous and its existence precarious, and there is a risk that its members may one day join the extremist elements $»^{22}$.

Conditions in the towns certainly bad enough to arouse anxiety. The urban refugees had even more cause to be restive than their rural counterparts since the assistance they had received from the RSC still left many families living in wretched conditions. According to Morgenthau, the task of housing them remained had been only partly completed by 1929 . In Salonika he found settlements where malaria and tuberculosis were rife, sanitation and heating arrangements primitive and privacy impossible to obtain: "Cooking is done in little charcoal braziers improvised out of tin cans and bricks. The roofs of these buildings leak with every rain and the walls are full of gaping cracks that let in the cold damp winds of winter. In visiting this settlement, wherever one's eye turns it is greeted by signs of human misery - death, disease, and bodily suffering and semi-starvation $»^{23}$. Those who lived in these shanty-towns received little support from the authorities. Property had been distributed among the refugees on the principle that those in the best position to pay for it would receive most. While this approach may have made sense in view of the extremely limited resources at the disposal of the Greek state, it contributed to the poorer refugees sense of alienation. "One would have expected", wrote Mikalis Notaras in his detailed study of the problem, «after the economic overturning of an enormous mass of people, of various social classes, ... that the bourgeois conception of property would have yielded to a more up-to-date, developed and consistent concept of justice whose balancing influence would have blunted social conflicts and grounded the banner of the postwar state more firm$1 y{ }^{24}$. The slump hit these urban refugees hard, particularly those employed at pitiful wages in trade and industry.

The tobacco workers, with their large refugee core, led the way in Salonika and Cavalla. The 1928 election had seen Venizelos win back their sympathies from the KKE, a fact not unrelated to the Liberal leader's open support for striking tobacco workers in the month before the election. At a pre-election

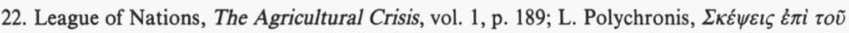

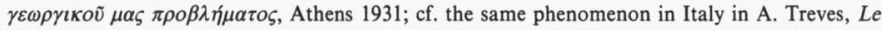
Migrazioni Interne nell' Italia Fascista, Turin 1976, chs. 7-8. The existence in Italy of a strong industrial lobby associated with the towns meant that the authorities stressed the danger to upublic order" rather than falling back on blanket denunciations of urban "parasitism" as they did in Greece.

23. Henry Morgenthau, I Was Sent to Athens, New York 1929, pp. 246-247.

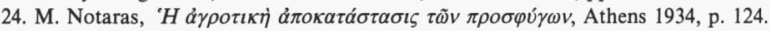


rally in Salonika Venizelos had pledged to introduce a labour policy favourable to the worker. What they got instead, of course, was the Idionymon, which gave the police sweeping powers of repression. In 1930 after months of harassment, the Idionymon was used to dissolve the workers' Tobacco Federation and its affiliates. Not surprisingly, the tobacco workers' response was to turn away from Venizelism again. Despite, or perhaps because of the very extensive political repression, directed through local Public Security committees, the workforce became increasingly radical in its demands. When Venizelos visited Cavalla on the eve of the 1932 election, he was greeted with such shouts of disapproval that he had to leave without speaking, an event which would have been unheard-of four years earlier. The culmination of refugee alienation would come in February 1934 with the election of Communist mayors in Cavalla and Serres ${ }^{25}$.

Many other refugees had started out in business during the 1920s as selfemployed traders, pedlars and shop-keepers. As we have seen, the RSC and the State had actually promoted the formation of small family firms. The Greek legal system encouraged a tendency to retail-trade fragmentation which the boom atmosphere of mid-decade also fostered. In Jannina - a town of around 20.000 inhabitants - there were 246 grocers, 137 cafes and 42 hairdressers. Local observers attributed the "excessive» number of shopkeepers in the Salonika area to the activity of the refugees who sought to take advantage of the inflation and easy credit to establish themselves as intermediaries, investing particularly heavily in import goods. Within a few years refugee traders were supposed to have ousted the Jews as the dominant element in commerce in Salonika. ${ }^{26}$

At the end of the 1920s, several forces combined to jeopardise the position of these small businesses. In the first place, the stabilization of the drachma ended the mild inflation of the mid-1920s; almost immediately after, deflation set in. As early as March 1929 the Ionian Bank's manager in Salonika was reporting that "the precarious state of commerce in our market becomes apparent from the frequent failures of big merchants and the frequent, almost daily fires in shops, several of which proved to be not casual». Wholesale prices peaked in the first quarter of 1929 , and by early 1930 had fallen almost ten per cent, dropping a further ten per cent over the rest of the year. In addition, poor

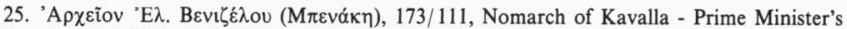
Political Office, 26 March 1932 gives a graphic illustration of the official mentality and the scale of

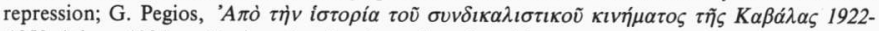
1953, Athens 1984 , p. 49 gives the view from the other side.

26. A. Pepelasis, «The legal system and economic development of Greece», Journal of Economic History, vol. 19, 2 (June 1959), 195; USNA, 868.00B/39, «Political and economic effects of the refugees in Greek Macedonia», 23/12/29. 
cereal harvests sharply curtailed peasant consumption. Traders who had tied up funds in stocks of imported goods (or for that matter tobacco) faced immediate losses. The banks, which in towns like Cavalla had been lavish in granting credits to refugee merchants, suddenly took fright after 1929. "The merchants in your market", a bank manager in Cavalla was informed by London head office, «have abused through over-trading to an unbelievable extent the facilities foolishly granted to them by Banks in their insane and inexperienced competition with each other and have to pay the prices. ${ }^{27}$ The farmers' debt moratorium tied up the fund of urban banks and investors and reduced aggregate demand in the towns. Some commentators also argued that cut-throat competition among new firms had led to a fall in profit rates which together with the eradication of speculative opportunities on the exchanges increased bankruptcies. Stephen Ladas noted in 1932 that while the poorest refugees had benefitted from the Liberal Government's large public works outlays, it was «the class of middlemen and of small traders that seems to be most severely suffering in the large cities». ${ }^{28}$

The longer-term political implications for Venizelism were critical. Alongside the refugees' shift to the Left which we referred to earlier occurred other realignments. In Salonika, commercial rivalry between Greek merchants and the large Jewish community fuelled growing anti-semitism. The first prominent sign of this was the appearance of a National Macedonian Organisation in 1926 which called for a commercial boycott against the Jews. The following year the National Union of Greece (EEE) was founded, with a mostly refugee membership; this organisation was responsible for the worst anti-semitic outrage of the inter-war period, the Campbell riots in Salonika in June 1931, when a Jewish neighbourhood was set on fire. Venizelos' condemnation of these events was lukewarm: he criticised the recourse to violence but expressed his sympathy with what he regarded as primarily an anti-communist nationalist organisation. ${ }^{29}$

Venizelos' previously secure grip on refugee loyalties was now slipping and other political leaders made bids for their support. During the parliamentary debate on the Ankara Convention in June 1930 Kafandaris, Kondylis and the Agrarians proclaimed their rejection of its terms. Most striking of all was the new attitude of the Populists. Tsaldaris, for the first time, added his voice to those who called for greater compensation for the refugees. As the crisis worsened, Populist overtures to the refugees met with some success. By the spring

27. IBA, Kavalla, General Manager (London) - Ziffo (Kavalla), 24 March 1930.

28. IBA, Salonika, HYR 1928/29, pl; Salonika, HYR 1929/30, pp. 1-4; Stephen P. Ladas, The Exchange of Minorities: Bulgaria, Greece and Turkey, New York 1932, p. 678.

29. G. Mavrogordatos, Stillborn Republic, Berkeley 1983, p. 255; USNA 868.00/660, Skinner (Athens) - State, 12/12/31. 
of 1932 Tsaldaris was able to deliver a speech at one of the main refugee quarters of Salonika - something which according to the American consul there "could not have happened a few years ago" ${ }^{30}$.

What, though, needs emphasizing at this point is the sanguine way in which many commentators and public figures interpreted the difficulties facing the urban refugees, and in particular, those in business. "Is there an economic crisis in Greece?» asked the Bulletin of the Bank of Athens in September 1929. Dimitris Sfikas gave a crisp answer: there was no crisis of any sort. The stabilisation of the drachma had, it was true, led to a new "spirit of economy" which restricted consumption and increased bankruptcies among the small firms which had sprung up over the last few years. But this was, according to him, a welcome development, a symptom of the long-desired «re-establishment» of the economy. In the 1920 s there had been «a truly stupefying growth» of traders, especially after the arrival of the refugees in the towns virtually all of whom, he added with some exaggeration, had gone into commerce. The current wave of bankruptcies was nothing more than a return to "the normal order of things $1{ }^{31}$ Another journalist drew the same conclusion, observing that two-thirds of the bankruptcies in the Athens-Piraeus area in $1928 \mathrm{had}$ liabilities of less than 100.000 drachmas, and chiefly involved small merchants $^{32}$. According to the British vice-consul there, there was «properly speaking, no economic crisis, only a surplus of entrepreneurs.» Early in 1930 the British commercial attache reported that «there is no doubt that the market will adjust itself at no distant date, and if the recent difficulties have had the result of eliminating a large number of unimportant commercial and industrial concerns, they will have served a good purpose ${ }^{33}$. In similar vein, Liberal Finance Minister George Maris insisted that "we shouldn't exaggerate our difficulties» - Greece was merely in a period of transition from inflation to stabilisation. And the Populists agreed: one senior figure, George Streit, said that the country was passing temporarily through a «businessman's crisis, due to over-speculation $)^{34}$.

There were several reasons why the slump was viewed with so little alarm. Proponents of business rationalisation - and there were many in Greece saw the crisis as the way in which market force's themselves would "prune» or "cleanse» the domestic economy of the inefficient firms founded in the "period

30. USNA 868.00/673, Morris (Athens) - State, 5 April 1932.

31. Banque d'Athènes, Bulletin, no. 85 (September 1929), p. 1539-1541.

32. ibid., no. 87 (November, 1929), 1591.

33. FO 371/13658 C8833/1124, Harvey - FO, 20 Nov. 1929; FO 371/14386 C1035/468, Ram-

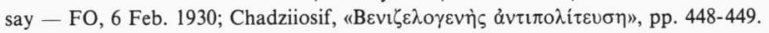

34. Banque d'Athènes, Bulletin, no. 89 (January 1930), pp. 1641-1642; USNA 868.00/626, Skinner (Athens) - State, 15 Jan. 1930. 
of gaspillage» in the 1920s. In an article entitled "The crisis and parasitism» a writer for Peitharchia described the need for a "new equilibrium» in which those businessman with adequate resources would survive and begin to operate "with thrift and good housekeeping (noikokyrosyni)". The Government was keen to downplay the impact of the slump in Greece for fear of weakening the country's credit standing abroad. But there was also the fact that before the autumn of 1931 it was quite plausible to argue - as did the pro-Liberal Ethnos - that in Greece one saw none of those «mournful indices which characterise the crisis in other countries $\|^{35}$.

There was no downturn in domestic manufacturing until 1932 - after the "battle for the drachma» had been fought and lost. True, ill-advised bank lending to industry had begun to cause liquidity problems for several commercial banks by 1930 . But overall lending levels remained surprisingly high. One of the country's most brilliant economists argued convincingly at the time that far from cutting credit, the Bank of Greece had pursued a deliberately expansionary policy after $1928^{36}$.

Although the impact of the slowdown in world trade hit export sectors hard, its effect on Greece's overall external account was cushioned for a time by several factors. Invisible earnings held up well; more importantly, import prices collapsed even faster than exports, yielding terms of trade gains to the national economy of around $30 \%$ between 1928 and 1932. This was chiefly because Greece, unlike the Danubian states, was a wheat importer on a massive scale and thus benefitted from lower world wheat prices. As import volumes did not begin to fall heavily until 1931, the reduction in the trade deficit was very largely due to the rapid fall in import prices.

In turn, however, this suggested that the Liberal Government, which publicised the country's terms of trade gains, was little justified in claiming the credit for the smaller deficit. Import consumption was being maintained at surprisingly high levels. Yet Venizelos insisted that there was no cause for alarm. He was optimistic by nature, as he readily confessed, but he also believed that his ability to convey that optimism to his countrymen accounted for much of his past success. When attacked in March 1930 over the budgetary position by his former Interior Minister, Zavitsianos, Venizelos responded: «I am sure that the Greek people will continue to follow those men who have resolute faith in the future, not those who see everything black and grim.» A few months later, speaking in the Macedonian town of Drama, he reiterated:

35. Banque d'Athènes, Bulletin, no. 85 (Sept. 1929), p. 1539; ibid., no. 101 (Jan. 1931), p. 1893.

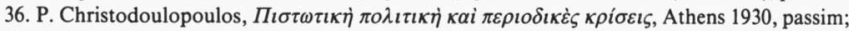
for further contemporary evidence, cf. IBA, Patras, YR 1930/31, 11; IBA. Salonika, YR 1930/31,

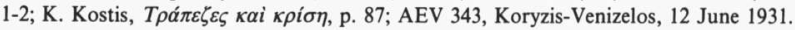


«My optimism consists in believing that everything will turn out for the best provided we work - as we are working - systematically ${ }^{37}$.

But Venizelos's optimism, which had been triumphantly justified in the heady days of the Balkan Wars, rang hollow amid the unmistakable signs of economic depression. Educated circles formerly supportive of the Lioberal leader began to distance themselves from his sanguine approach. In October 1929 Venizelist dissidents founded a new weekly, Peitharchia (Discipline), devoted to promoting "democracy with disciplined ideals" and outspokenly critical of what they regarded as Venizelos's excessive self-confidence. From its pages came a wide variety of criticisms of the Government, ranging from those who attacked the Liberal premier for his over-bearing role in his party, and his failure to organise it on less autocratic lines, to others, like the pro-Fascist Antonios Bernaris, who saw the only solution for a "disorganised" Greece in "a system of concentration, tough discipline, a dictator to direct production... an economist with the iron will of a Bismarck ${ }^{38}$.

If the Venizelist coalition had begun to come apart at the seams before the financial crisis, the failure to win the "battle for the drachma» was the last straw. The stringently deflationary policy pursued up to April 1932 led to increasing criticism of the Government, as well as riots and demonstrations which had to be broken up by force. The drachma's eventual departure from gold destroyed Venizelos's claims to economic competence even among his most committed supporters. The US consul in Salonika reported on 6 April, that "considerable discontent with the present government prevails, not only among those who are opposed to Venizelos in principle, but amongst the Liberals who supported him in $1928 \ldots$ Even the refugees, who have always supported Mr. Venizelos to the full have begun to show dissatisfaction with his present policies ${ }^{39}$. The KKE argued that the labouring classes had borne the brunt of defending gold. For the Agrarians, Pournaras argued that «the economic policy of the bourgeois state ceased long ago to have even superficially a popular basis ${ }^{40}$.

In this context, Venizelos' deliberate resuscitation of the issue of the dichasmos in the summer of 1932 had a quite precise electoral purpose. Its target was not the anti-Venizelist camp but the old elements of the 1928 Venizelist coalition which, he hoped, could be dragooned into accepting his leadership one more time. This strategy almost succeeded, but it revealed the extent to which the Liberal archigos felt challenged. Over time, the sense of threat grew:

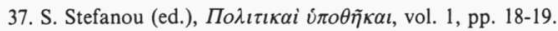

38. $\Pi \varepsilon \imath \theta \alpha \rho \chi i \alpha, 7$ Dec. 1930.

39. US National Archives, 868.00/673, Morris-State, 26 April 1932.

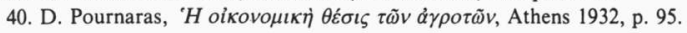


technocrats like Bernaris, admirers of Fascist Italy, criticised Venizelos for having offered Greece, not sound management but simply, an exaggerated picture of «a country of miracles». Venizelos's famous optimism was being thrown back in his face. Young economists, planners and social reformers looked on distastefully at the resurgence of "dichasmos" passions, and dreamed of an apolitical state run by "experts.» Meanwhile, the KKE's adoption of the Popular Front strategy allowed it to tap the disaffection of rural Greece more effectively. The strike wave which hit northern Greece in the spring of 1936 suggested that the main issue in Greek politics was no longer Venizelism versus anti-Venizelism: to some extent it was Athens versus the provinces; it was also "the bourgeois political world» against all signs of political or economic dissent. Whatever our judgement about the success or otherwise of the refugee resettlement in the long run, in the short-run it had clearly failed to secure the triumph of Venizelism: key sectors of the refugee population, such as the tobacco growers, tobacco workers and many urban traders, were forced into destitution by the economic crisis. From their viewpoint, the response of the Venizelist state was to meet their protests with increasingly vigorous police repression. The entire conflict was couched rather misleadingly in terms of communism versus the bourgeois order, and this sort of language showed how far inter-war Venizelism had abandoned its radical roots and travelled down the path to the Cold War. 